\title{
Does tourism contribute significantly to the Greek economy? A multiplier analysis
}

DOI 10.1515/ejthr-2016-0006

received October 20, 2014; accepted February 22, 2015

\begin{abstract}
Tourism is one of the growing service sectors in Greece. In 2014, the direct and indirect contribution of the Greek tourism industry to total GDP and employment reached $17.3 \%$ and $19.2 \%$, respectively (WTTC, 2015). As the economic importance of the tourism industry is growing among the policymakers and researchers, the objective of this paper is to analyse the contribution of tourism to Greek's economic growth. We use a trivariate model of real gross domestic product (GDP), international tourist expenditure and a real effective exchange rate, to calculate a tourism multiplier in order to assess the contribution of tourism to the economic growth. Using quarterly data for Greece during the period 2000q1 to 2013q2, we estimated results as a tourism multiplier of 1.21. We also estimated that the tourism industry generated an increase of 1.0\% in the Greek GDP for the year 2013.
\end{abstract}

Keywords: Tourism, Economic growth, Multiplier analysis; Greece.

\section{Introduction}

Tourism in Greece is an important economic activity which covers $43 \%$ of the services balance' total receipts. The net travel receipts (receipts minus payments) cover $58 \%$ of the surplus of the services balance (statistics of

*Corresponding author: Evangelia Kasimati, Economic Analysis \& Research Department, Bank of Greece, 21 El. Venizelos Ave, GR 102 50, Athens Greece, Tel: +30210 3202649; Fax: +30210 3233025, E-mail: ekasimati@bankofgreece.gr Athens Institute for Education \& Research, Head of Tourism Research Unit, 8 Valaoritou Str, GR 106 71, Athens Greece

"The views expressed in this paper are those of the author and do not necessarily reflect those of the Bank of Greece
2014). In 2014, Greece received $24.2 \mathrm{mn}$ international tourist arrivals (including cruise tourists), increased by $21 \%$ compared to year 2013, with leading markets being Germany, France and the United Kingdom. International tourist revenues at current prices amounted to $13.4 \mathrm{mn}$ Euros in 2014 compared to $12.2 \mathrm{mn}$ Euros in 2013, an increase of $10 \%$. The average per journey expenditure of tourists reached 552 euros in 2014, decreased by $9 \%$ compared to 2013. Employment in the sector, either direct or indirect, represented $19.4 \%$ of the total employment in the country, which means that 700,000 people were employed in tourism related activities throughout all sectors of the Greek economy (WTTC, 2015). Finally tourism, directly or indirectly, contributed 17.3\% of total GDP (WTTC, 2015).

On a global scale, the Greek tourism has shown a satisfactory performance. According to the latest data available from the World Tourism Organization (WTO), Greece in 2014, Greece ranked 15th in international arrivals and 19th in revenues. According to the World Economic Forum (WOF), in 2014, Greece occupied the 31st place among 141 countries in the index of Travel and Tourism Competitiveness, while rating 18th among the European countries. Moreover, Greece captured 3.3\% of the European and $1.4 \%$ of the worldwide tourism market.

Acknowledging the importance of tourism as a crucial factor in the Greek economy, during 2010-2013 a range of legislative initiatives were adopted, including the:

- Recognition of thermal springs and the licensing of thalassotherapy (seawater therapy) and therapeutic centres.

- Establishment of the GNTO's Special Service for Promoting and Licensing Tourism Enterprises, a "onestop-shop" for tourism enterprises.

- Simplification of the licensing procedure for tourism enterprises.

- Introduction of a new form of integrated tourism enterprise, the Complex Tourism Accommodation, which includes four-star or five-star hotel accommodation, special tourism infrastructure (e.g. conference centres, golf courses, spas) and tourist residences (villas).

- Liberalisation of the tourist guide profession. 
2003

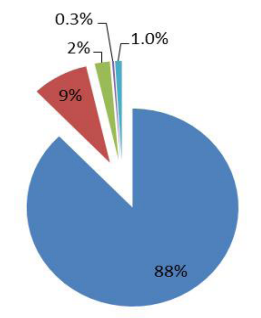

2012

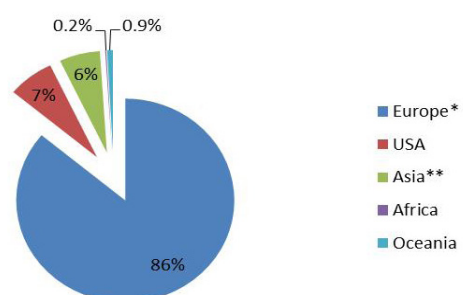

Figure 1: Development of tourist arrivals per continent

$\left.{ }^{(}\right)$Arrivals from Russia are included. ${ }^{* \star}$ ) Arrivals from Turkey are included.

Source: Bank of Greece, Bulletin of Conjunctural Indicators (2015).

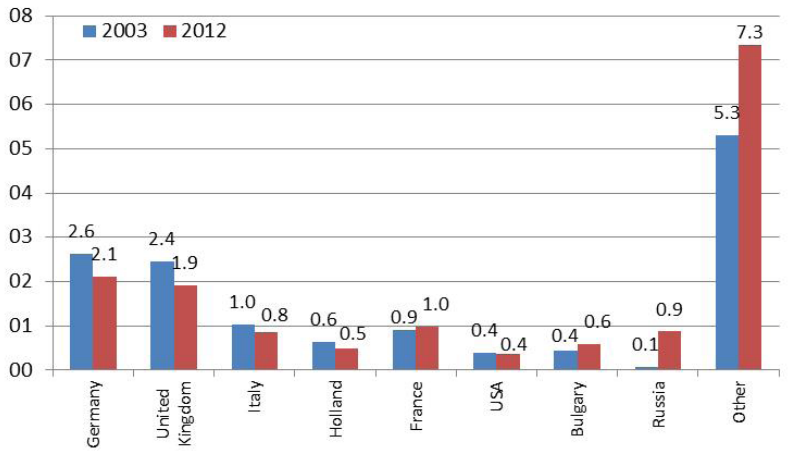

Figure 2: Arrivals of tourists in Greece between 2003 and 2012 (in million travellers)

Source: Bank of Greece, Bulletin of Conjunctural Indicators (2015).

- Simplification of procedures and the abolishment of limitations on the operations of travel agencies and car rental agencies.

- Legislative action encouraging the development of cruise, marine and fishing tourism.

- Lifting of cabotage fees.

- Simplification of visa procedures for new and emerging markets such as the Russian Federation, China and Turkey (OECD, 2014).

Although the legislative action aimed at developing both domestic and inbound tourism, a key feature of the Greek tourist product is the geographical distribution of demand from abroad with almost its entirety coming from the European continent. This pattern actually presents no substantial change in the last decade (Figure 1). In 2012, arrivals from European countries totaled $13.3 \mathrm{mn}$, out of which $74 \%$ came from the EU-27, while $44 \%$ were visitors from member countries of the Eurozone.

At a country level, Germany and the United Kingdom are long-lasting traditional markets from which Greece receives the largest number of foreign visitors, despite the fact that their shares have decreased in recent years. In 2012, the percentage of visitors from these countries reached $14 \%$ and $12 \%$ of total arrivals, whereas in 2003 they represented $19 \%$ and $18 \%$, respectively. In the last decade, new country markets emerged worldwide, out of which Greece has attracted significant numbers of visitors. Such countries, with significant Greek interest, include Russia as well as the neighbouring Balkan states, which partly offset the decline from other countries (Figure 2). In particular, arrivals from Russia have increased significantly over the last years (average annual growth rate of $38 \%$ in 2008-2012), while strengthening even more the tourism revenues, as the average expenditure per Russian visitor is nearly twice as much the level of the corresponding average of all foreign visitors ( $€ 1,079$ vs $€ 646$, respectively, in 2012). At the same time, the low number of visitors from countries such as Japan and China demonstrates the potential of other important markets from which Greece could benefit in the future by attracting a significant number of tourists.

The contribution of tourism to the economy is reflected in the Greek tourism revenues (i.e. the expenses of foreign visitors during their visits to Greece), which make $5.12 \%$ of the nominal GDP (average 2003-2012 decade).

This paper hopes to gain more current and applicable information about the economic contribution of international tourism through estimating a tourism multiplier for the Greek economy, to assist policy makers in appropriate planning. The rest of the paper is structured as follows. Section 2 provides a summary of the previous studies that examine the relationship between tourism and economic growth. Section 3 describes the data and a presentation of the methodology. Section 4 contains empirical results and their interpretation. Finally, Section 5 offers a summary and conclusions. 
Table 1: Comparison of the Empirical Results for Tourism Development and Economic Growth

\begin{tabular}{|c|c|c|c|c|c|c|c|}
\hline Samples & Authors & Empirical Method & Period & Countries & \multicolumn{3}{|c|}{ Causal Relationship } \\
\hline & Kasimati (2011) & VECM & 1960-2009 & Greece & Growth & $\Rightarrow$ & Tourism \\
\hline & Zortuk (2009) & VECM & 1992-2008 & Turkey & Tourism & $\Rightarrow$ & Growth \\
\hline & Oh (2005) & Granger Causality & $1975-2001$ & Korea & Growth & $\Rightarrow$ & Tourism \\
\hline & Gunduz\&Hatemi-J (2005) & $\begin{array}{l}\text { Vector Autoregressive } \\
\text { Model (VAR) }\end{array}$ & $1963-2002$ & Turkey & Tourism & $\Rightarrow$ & Growth \\
\hline & Dritsakis (2004) & VECM & $1960-2000$ & Greece & Tourism & $\Leftrightarrow$ & Growth \\
\hline & Durbarry (2004) & VECM & 1952-1999 & Mauritius & Tourism & $\Leftrightarrow$ & Growth \\
\hline & $\begin{array}{l}\text { Balaguer\&Cantavella-Jorda } \\
(2002)\end{array}$ & VECM & $1975-1997$ & Spain & Tourism & $\Leftrightarrow$ & Growth \\
\hline \multicolumn{8}{|c|}{ Cross-Section } \\
\hline & $\begin{array}{l}\text { Eugenio-Martin \& Morales } \\
\text { (2004) }\end{array}$ & $\begin{array}{l}\text { Panel Generalised } \\
\text { Least Squares (GLS) }\end{array}$ & 1980-1997 & $\begin{array}{l}\text { Latin American } \\
\text { Countries }\end{array}$ & Tourism & $\Rightarrow$ & Growth* \\
\hline & Lee $\&$ Chang (2008) & Panel cointegration & 1990-2002 & $\begin{array}{l}\text { OECD \& } \\
\text { non-OECD } \\
\text { countries }\end{array}$ & Tourism & $\Leftrightarrow$ & Growth \\
\hline
\end{tabular}

Notes: «Tourism=>Growth» denotes causality coming from tourism development to economic growth. «Growth=>Tourism» denotes causality running from economic growth to tourism development. «Tourism $=>$ Growth» denotes bidirectional causality between tourism development and economic growth.

* Exists for low- and middle-income countries but not for high-income countries.

\section{Tourism and economic growth: assorted studies}

In recent years, researchers have been interested in the relationship between tourism and economic growth, empirically supporting a direct effect from the first to the second. A general consensus that tourism increases foreign exchange income, creates employment opportunities and triggers overall economic growth has emerged. Therefore, tourism development has created a common awareness in political authority worldwide.

Table 1 displays the results of the studies on the tourism development and economic growth relationship conducted for different countries in different years employing different methods. In their analysis conducted for the Turkish economy, Zortuk (2009) and Gunduz and Hatemi-J (2005) concluded that the increase in tourism income positively affected economic growth. Oh (2005) found that the hypothesis of tourism-led economic growth could not be verified in the case of the Korean economy. The results of Oh's Granger causality test implied the existence of a one-way causal relationship in terms of economics-driven tourism growth. Similar to Oh's results,
Kasimati (2011) found no directional impact between tourism and economic growth in Greece. On the other hand, the analysis by Dritsakis (2004) to Greece, Durbarry (2004) to the Mauritius and Balaguer and CantavellaJorda (2002) to Spain empirically proved the existence of a bidirectional relationship between the two variables. In addition, Eugenio-Martin and Morales (2004) confirmed the validity of tourism-led growth hypothesis for low- and middle-income countries in Latin America while they asserted that the situation was different for high-income countries. Lee and Chang's study (2008), reviewing 32 selected countries, including both OECD and non-OECD countries, found that there was an unidirectional relationship coming from tourism towards the growth in OECD countries whereas a bidirectional causality relationship existed in non-OECD countries.

Given the aforementioned results of the studies, this paper aims to gain more relevant information about the economic contribution of international tourism by estimating tourism multiplier to the Greek economy. Estimation of the multipliers of tourism was conducted by researchers at a state or county level (Bryden, 1973; Archer, Sheila and Vane, 1974; Armstrong, Daniel and Francis, 1974; Liu and Var, 1983; Liu, 1986; Fasenmaier et al., 1989; Teisl and 
Table 2: The tourism multiplier of income in selected destinations

\begin{tabular}{llll}
\hline Region & Tourism multiplier & Region & Tourism multiplier \\
\hline United Kingdom & 1.73 & Malta & 0.68 \\
Ireland & 1.72 & Gibraltar & 0.66 \\
Sri Lanka & 1.59 & Iceland & 0.64 \\
Jamaica & 1.27 & Barbados & 0.60 \\
Egypt & 1.23 & Virgin Islands & 0.58 \\
Dominican Rep. & 1.20 & Palau & 0.51 \\
Seychelles & 1.03 & Victoria, Canada & 0.50 \\
Hong Kong & 0.87 & Carlisle, UK & 0.44 \\
Philippines & 0.82 & Edinburgh, UK & 0.35 \\
Bahamas & 0.79 & East Anglia, U.K. & 0.34 \\
\hline
\end{tabular}

Source: Cooper et al. (2008).

Reiling, 1990; Vilaplana, Pai and Hushak, 1991; Archer, 1995; Andrew, 1997) and nation-wide level (Diamond, 1976; Archer, 1985; Ruiz, 1985; Heng and Low, 1990; Khan, Seng and Cheong, 1990; Khan, Phand and Toh, 1995; Crespo and Diaz, 1997; Durbarry, 2002; Mazumder, Ahmed and Al-Amin, 2009). The exact value of the multiplier can vary from one situation to the other because it depends on the characteristics of the destination's economy, its social structure and the types of tourism it hosts (Candela and Figini, 2012). According to Lagos (2009), the smaller and consequently the less developed an area is, the smaller the tourism multiplier tends to be. The national tourism multiplier rarely exceeds the value of 2.0, whereas the relevant regional multipliers are always lower (around 0.5). Table 2 presents values of the multiplier for selected countries. We should keep in mind that such cross-country comparisons must be handled in with care, since the studies might have been conducted at different time periods or different methodologies might have been used (Cooper et al. 2008). In addition, although the value of a destination's tourism multiplier is seldom subject to significant variation and appears to be quite stable over time, it is nevertheless reasonable to expect that the overall impact will increase as the country's economy develops.

\section{Data and methodology}

There are several alternatives to measure the volume of tourism. One of them consists of tourist revenue, which represents the volume of earnings generated by foreign visitors. The second is the number of nights spent by visitors from abroad. The third is the number of tourist arrivals. This study makes use of tourist revenues to represent tourism. Given that the tourism-led growth hypothesis is about the contribution of tourism to the economic growth, real GDP is also included to represent the economic growth. Therefore, we estimate the following equation:

$$
{ }^{\ln } G D P R_{t}=\alpha+\alpha_{1} \ln T R R_{t}+\alpha_{2} \ln R E X R_{t}+\varepsilon_{t}
$$

where

$\operatorname{lnGDPR}=$ natural logarithm of gross domestic product at 2005 constant prices

$\operatorname{lnTRR}=$ natural logarithm of the tourist expenditure at 2005 constant prices 1

lnREXR $=$ natural logarithm of the real effective exchange rate $\varepsilon=$ the error term with the conventional statistical properties.

Many authors, such as Oh (2005), Gunduz and Hatemi-J. (2005), Dritsakis (2004) and Balaguer and Cantavella-Jorda (2002), suggest the inclusion of the real exchange effective rate in the discussion of international tourism in order to deal with potential overlooked variable problems and to account for external competitiveness.

The data are quarterly over the period 2000:Q1 to 2013:Q2, obtained from the Bank of Greece's Frontier Travel Survey, the Hellenic Statistical Authority and the European Central Bank (ECB). More specifically, the tourist expenditure data are collected from the Bank of Greece's Frontier Travel Survey, published at various issues of the Bulletin of Conjunctural Indicators; the GDP data are collected from the Hellenic Statistical Authority, published at various issues of the Statistical Authority's publication which is entitled "The Greek Economy"; the real effective exchange rate is obtained from the ECB's official website.

1 Tourism receipts do not include the cruise receipts as the latter is available only for the year 2012 and not for the whole period examined. 
The modelling strategy adopted in this study is based on the now widely used Engle-Granger methodology (Engle and Granger, 1987). Testing for co-integration involves two steps: the first step is to determine whether the variables that we use are stationary or non-stationary. If a series is non-stationary, then all the usual regression results suffer from a spurious regression problem. To this end, the augmented Dickey-Fuller (ADF) and PhillipsPerron (PP) tests of stationarity are performed both at the levels and the first differences of the variables (Dickey and Fuller, 1981; Phillips and Perron, 1988). Both the ADF and PP unit root tests use the various specifications of the following regression:

$\Delta x_{t}=\alpha+\beta x_{t-1}+\lambda_{t}+\sum_{i=1}^{k} \delta_{i} \Delta x_{t-i}+u_{t}$

where

$x_{t}=$ the level of the variable under consideration,

$t=$ time term,

$u_{t}=$ normally distributed random error term with zero mean and constant variance.

At the second stage, a co-integration test is performed to identify the existence of a long-run relationship. Johansen (1988) and Johansen and Juselius (1990) set out a model in error-correction form as follows:

$\Delta \mathrm{Z}_{t}=\Gamma_{1} \Delta \mathrm{Z}_{t-1}+\ldots+\Gamma_{k-1} \Delta \mathrm{Z}_{t-k+1}+\Pi \mathrm{Z}_{t-1}+\mu+\Psi D_{t}+\varepsilon_{t}$

where

$Z_{t}=\mathrm{a} \mathrm{p} \times 1$ vector of stochastic variables, comprised of real GDP, tourist arrivals and real effective exchange rate $\mu=$ a constant term
$D_{t}=$ a vector of non-stochastic variables

$\mathrm{k}=$ the lag length

$t=1, \ldots, T$

$\varepsilon_{t} \sim \operatorname{Niid}_{P}(0, \Sigma)$

If the data are integrated of order one $I(1)$, then the matrix $\Pi$ has to be reduced rank $r$ :

$\prod=\alpha \beta^{\prime}$

where $\alpha$ and $\beta$ are $p \times r$ matrices and $r<p$ and where $\beta^{\prime} Z_{t}$ are the $r$ long-run co-integration relations and $\alpha$ represents the error-correction parameters, which can be interpreted as speed of adjustment parameters.

Johansen (1988) and Johansen and Juselius (1990) suggest two test statistics to test the number of co-integrating vectors (or the rank of $\Pi$ ) in the VAR model, the trace ( $\mathrm{Tr}$ ) and the maximum eigenvalue (L-max) test. The likelihood ratio statistic for the trace test is

$\operatorname{Tr}=-T \sum_{i=r+1}^{p-2} \ln \left(1-\hat{\lambda}_{i}\right)$

where $\hat{\lambda}_{r+1}, \ldots, \hat{\lambda}_{p}$ are the estimated $p-r$ smallest eigenvalues.

The null hypothesis to be tested is that there are at most $r$ co-integrating vectors. That is, the number of co-integrating vectors is less than or equal to $r$, where $r$ is 0,1 , or 2 ..., and so on. In each case, the null hypothesis is tested against the general alternative. Alternatively, the $L$-max statistic is

$L-\max =-T \ln \left(1-\hat{\lambda}_{r+1}\right)$

Table 3: Results of unit root tests

\begin{tabular}{|c|c|c|c|c|}
\hline \multirow[b]{2}{*}{ Variable } & \multicolumn{2}{|c|}{ Augmented Dickey-Fuller (ADF) } & \multicolumn{2}{|c|}{ Phillips-Perron (PP) } \\
\hline & Levels & First differences & Levels & First differences \\
\hline $\operatorname{lnGDPR}$ & $-0.437(0.519)$ & $\begin{array}{l}-1.294 \\
(0.178)\end{array}$ & $0.303(0.769)$ & $-7.827(0.000)$ \\
\hline $\operatorname{lnTAR}$ & $-2.288(0.023)$ & $\begin{array}{l}-6.878 \\
(0.000)\end{array}$ & $0.155(0.727)$ & $-12.476(0.000)$ \\
\hline InREXR & $1.044(0.920)$ & $-6.184(0.000)$ & $0.879(0.896)$ & $-6.227(0.000)$ \\
\hline \multicolumn{5}{|c|}{ Critical Values } \\
\hline $1 \%$ & -2.609 & & -2.609 & \\
\hline $5 \%$ & -1.948 & & -1.948 & \\
\hline $10 \%$ & -1.613 & & -1.613 & \\
\hline
\end{tabular}

Note: Probabilities are in brackets. The optimal lags for the ADF tests are selected based on optimising Schwarz criterion using a range of lags. Tests for unit roots have been carried out on EViews 8.0. 
Table 4: Results of Johansen's maximum probability tests for multiple co-integrating relationships

Sample (adjusted): 2000Q3 2013Q2

Included observations: 52 after adjustments

Series: LNRGDP2005 LNRECEIPTS2005 LNREXR

Lags interval (in first differences): 1 to 1

\begin{tabular}{lllll}
\hline $\begin{array}{l}\text { Hypothesised } \\
\text { No. of CE(s) }\end{array}$ & Eigenvalue & $\begin{array}{l}\text { Trace } \\
\text { Statistic }\end{array}$ & $\begin{array}{l}0.05 \\
\text { Critical Value }\end{array}$ & Prob. $^{* *}$ \\
\hline None * & 0.958724 & 185.6198 & 35.19275 & 0.0000 \\
At most 1 & 0.300002 & 19.87104 & 20.26184 & 0.0565 \\
At most 2 & 0.025136 & 1.323795 & 9.164546 & 0.9037 \\
\hline \hline
\end{tabular}

Trace test indicates 1 co-integrating eqn(s) at the 0.05 level

* denotes rejection of the hypothesis at the 0.05 level

**MacKinnon-Haug-Michelis (1999) p-values

In this test, the null hypothesis of $r$ co-integrating vectors is tested against the alternative of $r+1$ cointegrating vectors. Thus, the null hypothesis $r=0$ is tested against the alternative that $r=1$, then $r=1$ against the alternative $r=2$ and so forth.

\section{Empirical analysis and findings}

Many macroeconomic time series contain unit roots dominated by stochastic trends as developed by Nelson and Plosser (1982). Knowing that unit root tests are sensitive to the presence of deterministic regressors, three models are estimated. The most general model with an intercept and time trend is estimated first and restrictive models, i.e. with an intercept and without either intercept or trend, respectively, are estimated thereafter. Unit root tests for each variable are then performed at both levels and first differences of variables. Table 3 reports the results for both the ADF and PP test results for only the model with neither intercept nor trend. It can be seen that the null hypothesis of non-stationarity cannot be rejected at the $5 \%$ level for the levels of all the variables. However, when first differences are taken, the null hypothesis of non-stationarity is rejected in all the variables. Hence, it is concluded that the three variables are integrated of order one $I(1)$. This result is consistent to the finding of Nelson and Plosser (1982) that most of the macroeconomic variables are non-stationary at level, but they are stationary after first differencing.

Given that all the variables are integrated in the same order, the next step is to test for co-integration using Johansen's trivariate maximum probability procedure. Johansen (1988) suggests two probability ratio tests for the co-integration rank, a maximum eigenvalue test and a trace test. Results of both tests are reported in Table 4, where $r$ represents the number of co-integrating vectors. When applying the co-integration test, we choose the case 2 assumption, where the level data have no linear trend but the co-integrating equations have only intercepts.

Table 4 indicates that there is one co-integrating equation. This means that although the three variables are I(1), there is also one stationary linear combination, i.e. the variables are co-integrated at $\mathrm{C}(1)$. As the co-integration hypothesis is accepted, the equation is estimated in levels with the canonical co-integrating regression. The coefficients are all statistically significant and they all have the expected sign. The probabilities for the individual parameters are in brackets. The results are represented below:

$$
\begin{aligned}
\ln G D P R_{t}= & 16.674+0.0661 \ln T R R_{t}+1.399 \ln R E X R_{t}+\varepsilon_{t} \\
& (0.000)
\end{aligned}
$$

$R$-squared $=0.608$

Adjusted $R$-squared $=0.593$

The regression findings show that an increase of the real tourist revenues by $10 \%$ results to an increase of the real GDP by $0.661 \%$. The coefficient $(0.661 \%)$ is the elasticity of real GDP according to the real tourist revenues, since the equation is expressed in logarithms. Given the multiplier's definition, the tourism multiplier for Greece is calculated as follows:

Tourism Multiplier $=$ $=\mathrm{e}(\overline{G D P R} / \overline{T R R})=0.0661(46.4 / 2.53)=1.21$

where

$\overline{G D P R}=$ the average value of real GDP during the period examined 
$\overline{T R R}=$ the average value of real tourist expenditure during the period examined

Since the tourism multiplier is larger than one, tourism can be considered as a development factor (Candela \& Figini, 2012). The obtained multiplier of 1.21 estimates that the expected increase of real tourist receipts by $15 \%$ in 2013 will have a positive increase on the real GDP by $1.0 \%$. This finding is far from the result of FEIR (2012) that calculated a tourism multiplier of 2.2 using an input-output analysis. However, a paper by Alcidi and Gros (2012) estimating a Keynesian multiplier for Greece to 1.4 concluded that this multiplier was the largest among Italy, Ireland and Spain. As Candela \& Figini (2012) reports, the differences in the multipliers' estimations depend on the types of tourism the destination economy hosts, the characteristics of its economy and its social structure.

\section{Summary and conclusions}

This study uses a trivariate model of real GDP, international tourist expenditure and real effective exchange rate, in order to calculate a tourism output multiplier to gauge the significance of tourism in generating output. Using quarterly data for Greece over the 2000-2013 period and since the variables in this paper are non stationary and present a unit root, Johansen's co integration technique is applied. This methodology allowed us to obtain a co integrating relationship among the three variables and to apply the canonical co integrating regression.

The model reveals a tourism multiplier of 1.21 , while the tourism industry produced an increase of $1.0 \%$ in the GDP in 2013. The obtained tourism multiplier of 1.21 reveals several interpretations. Firstly, Greek tourism industry not only plays an important role by generating output, income, value-added, but it also creates spillover effects on other tourism related sectors of the economy. Secondly, the results that have been estimated in this study can be considered as a guideline to the tourism industry policy makers, allowing them to take appropriate actions in developing and implementing policies and then to focus their attention on promoting those areas of tourism where direct, indirect and induced effects are higher. According to Mazumder et al (2009), the multiplier analysis is the best element in policy making that must be taken into account before decisions are made.

Although the model performs well, some expansions however, would be necessary in order to fully satisfy future research. Since the tourism industry has strong inter-sectoral linkages with other sectors of the economy, our model could be expanded to derive multipliers in terms of income, employment, sales/transaction, government revenue, and import for the Greek economy. In addition, appropriate expansions of the model could identify and measure the direct, indirect and induced effects of any change in tourist expenditures in the Greek economy.

\section{References}

[1] Alcidi, C., \& Gros, D. (2012). Why is the Greek economy collapsing? A simple tale of high multipliers and low exports. CEPS Commentary, 21 December.

[2] Andrew, B.P. (1997). Tourism and the economic development of Cornwall. Annals of Tourism Research, 24(3), 721-735.

[3] Archer, B.H. (1985). Tourism in Mauritius: An Economic Impact Study with Marketing Implications. Tourism Management, 6(1), 50-54.

[4] Archer, B.H. (1995). The impact of international tourism on the economy of Bermuda, 1994. Journal of Travel Research, 34(2), 27-30.

[5] Archer, B.H., Sheila, S., \& Vane, R. (1974). Tourism in Gwynedd and Economic Study, Cardiff: Wales Tourist Board.

[6] Armstrong, W.E., Daniel, S., \& Francis, A.A. (1974). A structural analysis of the Barbados economy, 1968, with an application to the tourist industry. Social and Economic Studies, 23(4), 493-520.

[7] Balaguer, J., \& Cantavella-Jorda, M. (2002). Tourism as a long-run economic growth factor: the Spanish case. Applied Economics, 34, 877-84.

[8] Bank of Greece (2015). Bulletin of Conjunctural Indicators, various issues.

[9] Bryden, J.M. (1973). Tourism and Development: A Case Study of the Commonwealth Caribbean, Anglia: Overseas Development Group, University of East Anglia.

[10] Candela, G. \& Figini, P. (2012). The Economics of Tourism Destinations. Springer-Verlag Berlin Heidelberg.

[11] Cooper, C.P. Fletcher, J., Gilbert, D., Shephard, R., \& Wanhill, S. (2008). Tourism: Principles and Practice. 4th edition, New York: Longman.

[12] Crespo, N., \& Diaz, S.N. (1997). Cuban Tourism in 2007: Economic Impact. [Online] Available: http://lanic.utexas.edu/ $\mathrm{la} / \mathrm{cb} / \mathrm{cuba}$ /asce/cuba7/crespo.pdf (August 2, 2005).

[13] Diamond, J. (1976). Tourism and Development Policy: A Quantitative Appraisal. Bulletin of Economic Research, 28(1), 36-50.

[14] Dickey, D., \& Fuller, W.A. (1981). Likelihood ration statistics for autoregressive time series with a unit root. Econometrica, 49, 1057-1072.

[15] Dritsakis, N. (2004). Tourism as a long-run economic growth factor: an empirical investigation for Greece using a causality analysis. Tourism Economics, 10, 305-316.

[16] Durbarry, R. (2002). The economic contribution of tourism in Mauritius. Annals of Tourism Research, 29(3), 862-865.

[17] Durbarry, R. (2004). Tourism and economic growth: the case of Mauritius. Tourism Economics, 10, 389-401. 
[18] Engle, R.F., \& Granger, C.W.J. (1987). Cointegration and error correction: representation, estimation and testing, Econometrica, 55, 251-276.

[19] Eugenio-Martin, J.L., \& Morales, N.M. (2004). Tourism and economic growth in Latin American countries: A panel data approach. Social Science Research Network Electronic Paper.

[20] European Central Bank (2015). Statistical Data Warehouse, http://sdw.ecb.europa.eu/browse.do?node $=2018795$.

[21] Fasenmaier, D.R., Jones, L., Um, S., \& Ozuna, T. (1989). Assessing the economic impact of outdoor recreation travel to the Texas gulf coast. Journal of Travel Research, 28(1), 18-23.

[22] Foundation for Economic \& Industrial Research (FEIR). (2012). The impact of tourism in the Greek economy. September 2012 (in Greek).

[23] Gunduz, L., \& A., Hatemi-J. (2005). Is the tourism-led growth hypothesis valid for Turkey?. Applied Economics Letters, 12(8), 499-504.

[24] Heng, T.M., \& Low, L. (1990). Economic Impact of Tourism in Signapore. Annals of Tourism Research, 17(2), 246-269.

[25] Hellenic Statistical Authority (2015). The Greek Economy, various issues.

[26] Johansen, S. (1988). Statistical analysis of cointegrating vectors. Journal of Economic Dynamics Control, 12, 231-254.

[27] Johansen, S., \& Juselius, K. (1990). Maximum likelihood estimation and inference on cointegration with applications to the demand for money. Oxford Bulletin of Economics and Statistics, 52, 169-210.

[28] Kasimati, E. (2011). Economic Impact of Tourism on Greece's economy: cointegration and causality analysis. International Research Journal of Finance and Economics, 79, 79-85.

[29] Khan, H., Phang, S., \& Toh, R.S. (1995). Singapore's Hospitality Industry: The Multiplier Effect. Cornell Hotel and Restaurant Administration Quarterly, 36(1), 64-74.

[30] Khan, H., Seng, C.F., \& Cheong, W.K. (1990). Tourism Multiplier Effects on Singapore. Annals of Tourism Research, 17(3), 408-409.

[31] Lagos, D. (2009). Multiplier Analysis and Tourism Development. 2nd International conference: Quantitative and Qualitative methodologies in the Economic and Administrative Sciences, TEl of Athens: 25-27 May 2009.

[32] Lee, C.C., \& Chang, C.P. (2008). Tourism development and economic growth: a closer look at panels. Tourism management, 29, 180-192.

[33] Liu, J.C. (1986). Relative economic contributions of visitor groups in Hawaii. Journal of Travel Research, 25(1), 2-9.

[34] Liu, J.C., \& Var, T. (1983). The economic impact of tourism in Metropolitan Victoria, BC. Journal of Travel Research, 22(2), 8-15.

[35] Mazumder, M.N.H., Ahmed, E.M., \& Al-Amin, A.Q. (2009). Does Tourism Contribute Significantly to the Malaysian Economy? Multiplier Analysis Using I-O Technique. International Journal of Business and Management, 7(4), 146-159.

[36] Montalvo, J.G.(1995). Comparing cointegrating regression estimators: some additional Monte Carlo results. Economics Letters, 48, 229-234.
[37] Nelson, C.R., \& Plosser, C.I. (1982). Trends and Random Walks in Macroeconomic Time Series: Some evidence and implications. Journal of Monetary Economics, 10, 139-162.

[38] OECD (2014). Country Profiles: Tourism Trends and PoliciesGreece. OECD.

[39] Oh, C.O. (2005). The contribution of tourism development to economic growth in the Korean economy. Tourism Management, 26, 39-44.

[40] Phillips, P.C.B., \& Perron, P. (1988). Testing for a unit root in time series regression. Biometrika, 75, 335-346.

[41] Ruiz, A.L. (1985). Tourism and the economy of Puerto Rico: An Input-Output Approach. Tourism Management, 6(1), 61-65.

[42] Teisl, M.F., \& Reiling, S.D. (1990). Tourism and Local Government expenditures and revenues. The Maine Business Research Report Agricultural and Resource Economics Staff Paper. Maine: University of Maine.

[43] Vilaplana, J., Pai, D.Y., \& Hushak, L.J. (1991). Supply side benefits of fisheries: estimation of economic impacts using IMPLAN. In paper presented at the IMPLAN Workshop. Columbus, $\mathrm{OH}$ : The Ohio State University.

[44] WOF. (2013). The Travel \& Tourism Competitiveness Report 2013. World Economic Forum.

[45] WTTC. (2013). Greece: Travel and Tourism Economic Impact, London: World Travel \& Tourism Council.

[46] WTTC. (2014). Greece: Travel and Tourism Economic Impact, London: World Travel \& Tourism Council.

[47] Zortuk, M. (2009). Economic Impact of Tourism on Turkey's economy: Evidence from Cointegration Tests. International Research Journal of Finance and Economics, 25, 231-239.

Evangelia Kasimati is an economist at the Central Bank of Greece and head of tourism research unit at the ATINER Institute. Prior to this, she was a research fellow in tourism economics and econometrics at the Centre for Planning and Economic Research, Athens, and she has also been a visiting research fellow at the Dept. of Economics, University of Bath. Her research and teaching interests lie in the areas of financial economics, tourism \& sports economics and macroeconomics. She has published her work in international academic journals and she has been a speaker in various international conferences. She has taught executive seminars for the Athens Exchange, as well as undergraduate courses in the Dept. of Economics and the Social and Policy Sciences at the University of Bath, the Dept. of Economics at the University of Peloponnese, the Dept. of Tourism Management and the Dept. of Health Care \& Social Units Administration at the TEI of Athens and the Dept. of Accounting at the TEI of Piraeus, Greece. She currently teaches a postgraduate course in the Dept. of Tourism Management at the Hellenic Open University. She has worked as a senior economist in several Greek banks. 